\title{
Den slesvig-holstenske patriotiske Forening 1845-1850
}

\author{
af HANS SCHULTZ HANSEN
}

Den danske bevægelses gennembrud i Nordslesvig i 1840'erne blev allerede i begyndelsen af vort århundrede grundigt skildret af Peter Lauridsen i værket „Da Sønderjylland vaagnede«. Derimod er det stadig småt med vor viden om hjemmetyskhedens samtidige fremvækst. Landsarkivar, Ph.D. Hans Schultz Hansen, der forsker i den nordslesvigske tyskheds historie indtil 1914, skriver her om hjemmetyskheden på Haderslevegnen og »Den slesvig-holstenske patriotiske Forening « i 1840'erne.

\section{Indledning}

1843 blev den danske agitations gennembrudsår i Nordslesvig - eller i hvert fald på Haderslevegnen. Peter Hiort Lorenzens danske tale i den slesvigske stænderforsamling i november 1842 gav her startskuddet til en række danske manifestationer: Festen i Sommersted kro den 21. februar 1843, købet af Skamlingsbanken og den første folkefest dér den 18. maj, oprettelsen af "Den slesvigske Forening “ den 12. juni og endnu en folkefest $i$ Gram slotshave den 18. september. ${ }^{1}$

Denne begyndende nationale mobilisering vakte imidlertid ikke kun begejstring; den rejste også modstand. For bondebefolkningen var den nationalpolitiske sag noget nyt og fremmed, som truede landsbyernes fred og sammenhold. Kun et mindretal engagerede sig nationalt, mens flertallet forholdt sig afventende. Nogle vendte sig endog direkte imod den danske bevægelse.

Blandt stifterne af Den slesvigske Forening var kroværten i Sommersted Paul Therkelsen Samsøe. Den 25. november 1843 erklærede han imidlertid sin udtræden i den delvist dansksprogede Haderslevavis »Lyna«, der redigeredes i slesvig-holstensk ånd. Det samme gjorde et andet medlem, gårdejer J. Fr. Lorenzen fra Kestrup. De var begge blevet betænkelige ved Den slesvigske Forenings reelle formål: "Er det måske hertugdømmet Slesvigs bestående forhold til Danmark, man vil forandre? - Da skal man ikke juble for hastig; thi det slesvigske folk vil uden tvivl nok vide at hævde sin selvstændighed, det 
lader sig ikke så let tage på slæbetov, som man - måske - formoder «. ${ }^{2}$ Det var med andre ord bekymringen for, at Den slesvigske Forening skulle gå Ejderdanskernes ærinde og medvirke til Slesvigs indlemmelse $\mathrm{i}$ kongeriget, som fik de to til at vende foreningen ryggen. Også et andet stiftende medlem af Den slesvigske Forening og Skamlingsbankeselskabet, gårdejer og sognefoged Conrad Iversen i Fredsted, meldte sig på samme tid ud i protest. ${ }^{3}$

\section{"Sogneopstandene« 1843-1844}

Samsøe og Lorenzen stod ikke alene med deres bekymring for, at en indlemmelse af Slesvig i kongeriget skulle være det skjulte formål for Den slesvigske Forening. I december 1843 erklærede 55 beboere $\mathbf{i}$ Hoptrup sogn med sognefoged E. E. Ladegaard i spidsen i "Lyna" deres utilfredshed med »den såkaldte nordslesvigske forening, som angivelig vil arbejde på undervisningsvæsnets forbedring, men som efter formændenes bedrifter at dømme, opkaster sig til formynder for det nordslesvigske folk, for at lede dette efter deres vrange anskuelser «. ${ }^{4}$ Denne erklæring var den første i rækken af såkaldte »sogneopstande", hvor et antal sogneboere underskrev en protest vendt imod den dansk-nordslesvigske bevægelse og indsendte den til offentliggørelse i "Lyna«. I løbet af første halvår 1844 bredte denne modbevægelse sig til Aastrup, Vilstrup, Bjerning, Skodborg, Starup, Magstrup, Vedsted og Stepping sogne i Haderslev amt samt til Løjt sogn i Aabenraa amt. ${ }^{5}$

"Sogneopstandene« havde forskellig ordlyd, men grundtonen $i$ dem var den samme. Underskriverne var imod "partiånd «, »uro« og den "fordærvelige uenighed " og fordømte dem, der som Den slesvigske Forening, den danske Haderslevavis "Dannevirke" og den kongerigske presse udsåede "tvedragtens onde sæd «. Sogneadresserne var derimod ment som "fredensord" vendt mod "den danske propaganda

Først og fremmest repræsenterede sogneerklæringerne en udpræget konservativ tankegang. Underskriverne ville beholde de »ældgamle bestående indretninger ( Hoptrup), de »velerhvervede rettigheder" (Aastrup) og "vore ejendommelige landsrettigheder og vort hele statsretslige forhold“ (Vilstrup). Hertil hørte Slesvigs selvstændighed og hertugdømmets nedarvede forbindelse med Holsten: „Vi ønsker at forblive hvad vi er, nemlig slesvigere, og vil på ingen måde 
skilles fra vore holstenske brødre« (Aastrup). En indlemmelse af Slesvig i kongeriget blev derfor afvist og alle bestræbelser herpå fordømt. Slesvigernes traditionelt nedladende syn på jyderne stak undertiden frem. I Aastrup mente man således, at københavnerne hellere måtte gøre noget for det primitive undervisningsvæsen i de jyske hedeegne end i Slesvig, og i Magstrup mente man, at Den slesvigske Forening burde kalde sig "den blandede jydsk-slesvigske forening «.

Men omvendt ville underskriverne ikke nogen adskillelse fra Danmark; også i denne henseende skulle det bestående fortsætte. I Vilstrup forsikrede underskriverne, at de ikke nærede had til Danmark: »Langtfra at vi føler nogen had og fjendskab imod det danske; meget mere agter vi det danske folk som gode og tro naboer ...«. I Aastrup talte man såvel om "danske medbrødre" som "holstenske brødre " og skrev: "Vi føler også vor forpligtelse med hensyn til Danmark, og erkender at vi med dette danner een stat, ligesom to sogne med forskellige kommunale indretninger meget vel kunne være forenede til et pastorat eller flere herreder under en foged «. Sogneerklæringerne udtrykte loyalt ærbødighed over for "vor allernådigste konge" (Aastrup), "vor allernådigste landsfader (Løjt) og »vor gode og vise konge" (Stepping).

Holdningen til det danske sprog som sådant var positiv: »Vi elsker vort modersmål, det sprog, hvori vi stammede vore første tanker, og fik vor første undervisning, som tjener os i det daglige livs sysler og forretninger, og hvori vi opløfter vore tanker til Gud, vi holder fast på vort sprog ...« (Hoptrup). Men sproget måtte ikke blive et politisk stridsspørgsmål og kunne ikke være et kriterium for menneskeværd endsige for nationaliteten: "Men uagtet vi elsker vort modersmål, så ved vi ret vel, at samme ikke begrunder vor nationalitet, og at indvånerne $\mathrm{i}$ vort hertugdømme, omendskønt de taler tre forskellige sprog, dog alle som slesvigere har een og samme nationalitet« (Bjerning). I Vilstrup talte man derimod om "vor hele slesvig-holstenske nation«. Også i Aastrup var tonen mere slesvig-holstensk.

Da »sogneopstandene« kom frem, var spørgsmålet om benyttelse af det danske sprog i den slesvigske stænderforsamling et hedt stridsemne. Sogneerklæringerne afviste med praktiske grunde, at der kunne finde en sproglig ligeberettigelse sted i stændersalen. Det kunne kun besvære og fordyre institutionen, hvis andre sprog end det højtyske skulle være det officielle. Dansk måtte højst benyttes i ganske få undtagelsestilfælde af deputerede, som ikke var det tyske sprog 
mægtige, og iøvrigt burde man undgå at vælge sådanne ukyndige repræsentanter. Underskriverne fra Aastrup forsikrede, at de elskede og benyttede det danske sprog, men de forgudede det ikke og ønskede »intet mere end daglig at skride frem i færdighed i det tyske sprog, som altid mere og mere bliver os uundværligt«. I Stepping så man tilmed noget positivt i sprogreskriptet fra 1840, der havde indført dansk rets- og forvaltningssprog i Nordslesvig. Det var nemlig "kommet især tjenestetyenderne og andre, som ikke kunne forstå tysk, til ædel gavn «; men tillige understregedes: "ligeså nyttig er det for vor egn, som ligger mellem det danske og det tyske, og som er mere $\mathbf{i}$ berørelse med syd end med nord, at vi kunne noget tysk«. I forlængelse heraf ønskede man flere steder hertugdømmernes økonomiske selvstændighed opretholdt.

Det er bemærkelsesværdigt, at der også var krav og opfattelser, som ikke kom til orde i "sogneopstandene«. Således forlangte ingen af de deltagende sogne en forening af de holstenske og slesvigske stænder, skattebevillingsret til stænderne eller en fri forfatning, og der var ingen hentydninger til hertugen af Augustenborgs arveret eller omtale af kongen som "hertug " eller "landsherre «. Sådanne mærkesager og markeringer, som var fremtrædende i den slesvig-holstenske bevægelse, savnedes ganske.

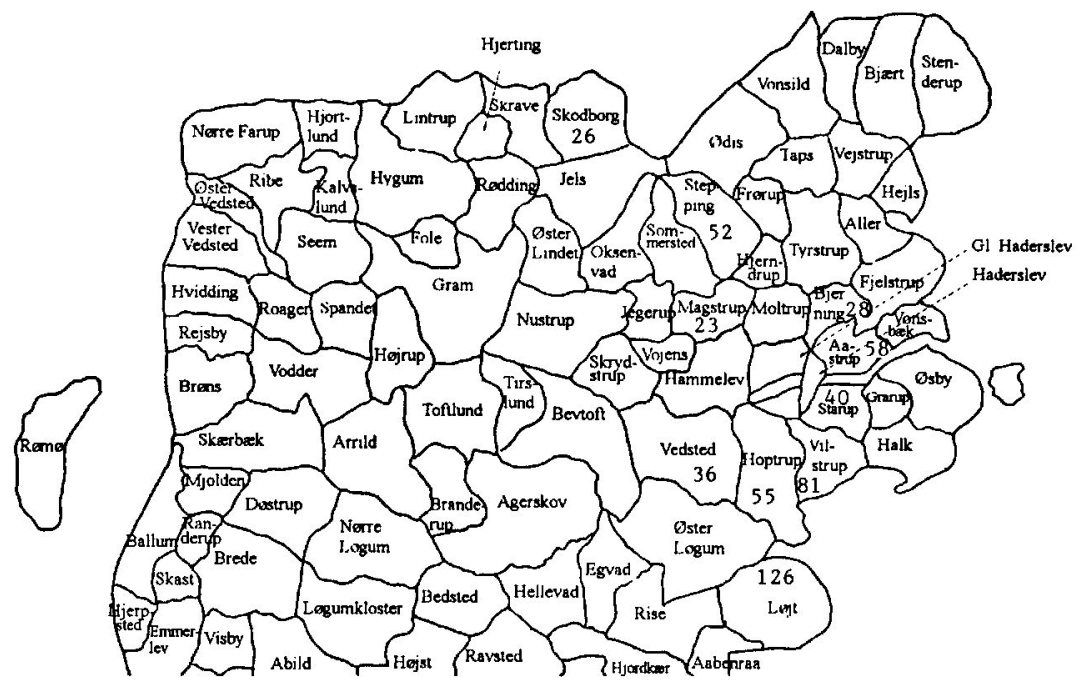

Kort 1: "Sogneopstandene« 1844. Antal underskrifter fra de deltagende sogne. 
Ialt fik de 10 protesterklæringer 525 underskrifter (se kort 1), hovedsagelig i sognene tæt på Haderslev og formentlig altovervejende fra gårdmandsstanden. ${ }^{6}$ Det var i sig selv ikke så få. Hvis holdningen i de 10 sogne tillige var repræsentativ for de andre sogne på Haderslevegnen, antydede "sogneopstandene " et betydeligt potentiale for en modbevægelse rettet imod Den slesvigske Forening og "Dannevirke« - en modbevægelse som måske kunne drejes fra den konservative slesvigske særfølelse over i en udtalt slesvig-holstensk retning.

"Dannevirke « betegnede underskriverne som tysksindede og insinuerede, at "sogneopstandene" var manipuleret frem af folk udenfor bondestanden. ${ }^{7}$ Om dette står til troende, får stå hen; et fyldestgørende svar kan næppe gives på det foreliggende kildegrundlag. ${ }^{8}$ »Opstanden«s langstrakte forløb og erklæringernes forskellige ordlyd og nuancer tyder dog ikke umiddelbart på en udefra iværksat og koordineret aktion - og $\mathrm{i}$ så fald gengiver protesterne naturligvis uden videre underskrivernes meninger. Men selv hvis "opstandene“, som påstået af "Dannevirke«, skulle være helt eller delvist styret af slesvigholstenske ledere udefra, udtrykker de formentlig alligevel underskrivernes velovervejede holdninger. Fraværet af klare slesvig-holstenske mærkesager kan nemlig i givet fald ses som et resultat af initiativtagernes realistiske vurdering af, hvad befolkningen kunne bringes til at skrive under på, og det betydelige antal underskrifter kan så tages som tegn på, at de heri havde ramt rigtigt.

\section{"Sognefogedforeningen « 1844-45}

På syv ud af de ti »sogneopstande« var den lokale sognefoged fremhævet som underskriver, som regel som den første. Også på anden vis markerede en række sognefogder deres utilfredshed med Den slesvigske Forening. I januar 1844 erklærede f.eks. seks sognefogder i Tyrstrup herred, at de ikke havde skrevet under på Den slesvigske Forenings petition om forflyttelsen af stænderforsamlingen til Flensborg. De delte heller ikke foreningens kritik af embedsmændene og fremhævede, "at det tyske sprog er os lige så kært som det danske og det danske som det tyske, thi begge er os agtværdige; og hvad det politiske angår, da ønsker vi fremtidig som hidtil at beholde de indretninger, som vore forfædre og vi selv hidtil har haft «. ${ }^{9}$ Den 29. marts 1844 erklærede ti sognefogder, at de ikke ville benytte den nyoprettede filial af den danske Nationalbank i Flensborg og at slesvi- 
gerne ikke behøvede de danske rigsbanksedler, som ville blive sat $\mathrm{i}$ cirkulation fra filialen. De understregede over for deres »sydslesvigske brødre«, at de ikke stod tilbage i "patriotisme og kærlighed for vort elskede Slesvig «. ${ }^{10}$

Denne sidste erklæring var blevet til på et møde i Haderslev, hvortil var indkaldt de sognefogder på Haderslevegnen, som ikke var medlemmer af Den slesvigske Forening. På mødet vedtog de tillige at danne en Sognefogedforening, der skulle mødes kvartalsvis i Haderslev. Foreningen skulle også være åben for "gårdmænd eller lige ansete«. De 15 stiftende medlemmer var følgende sognefogder: Knud B. Nissen fra Vilstrup, E. E. Ladegaard fra Skærbæk i Hoptrup sogn, J. Callesen fra Kirkeby i Hoptrup sogn, Conrad Iversen fra Fredsted i Gl. Haderslev sogn, P. Hansen fra Magstrup, Claus P. Berg fra Ødis, Claus K. Nissen fra Stepping, Niels Lauenborg fra Skodborg, Chr. Rasmussen fra Højrup i Stepping sogn, T. Detlefsen fra Hjerndrup, J. Jürgensen fra Favstrup i Tyrstrup sogn, H. Buchholz fra Aller, N. H. Posselt fra Frørup, Ph. Reggelsen fra Errigsted i Bjerning sogn og Chr. Juhl fra Aastrup. ${ }^{11}$

Oprettelsen af Sognefogedforeningen skal ses i sammenhæng med, at 15 andre sognefogder på Haderslevegnen 1843-44 var indtrådt i Den

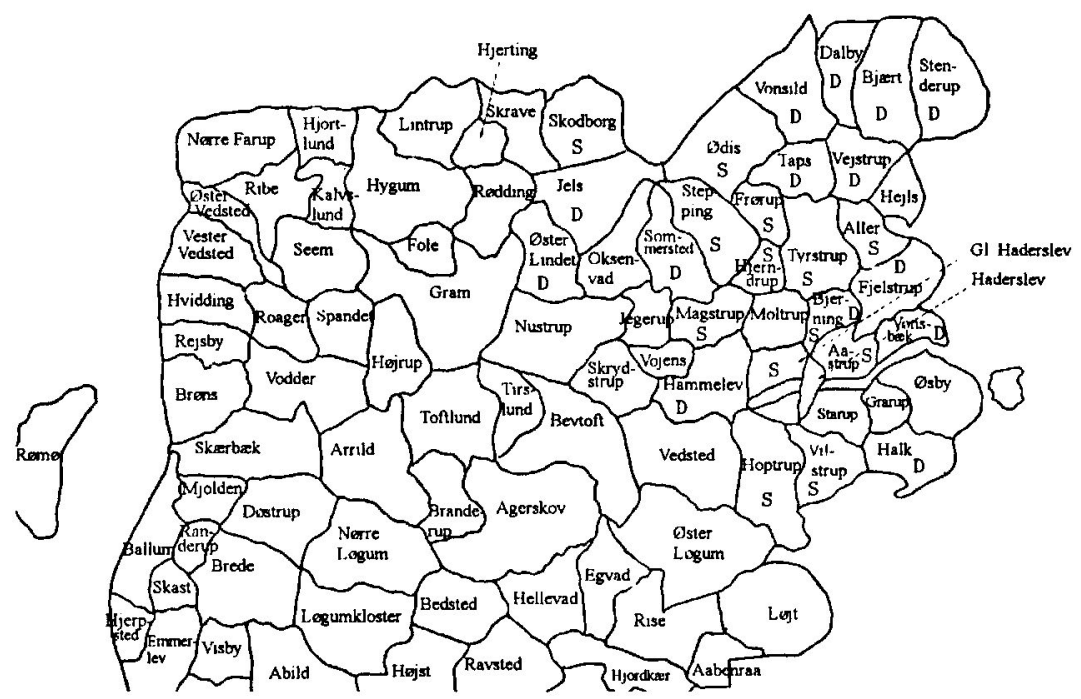

Kort 2: Sognefoydernes stillingtagen 1843/44.

$D=$ medlemskab af Den slesvigske Forening. $S=$ medlemskab af Sognefogedforeningen.

(Bjerning sogn havde to sognefogder). 
slesvigske Forening. ${ }^{12}$ Dermed var langt de fleste sognefogder i Haderslev Østeramt engageret enten for eller imod den frembrydende danske bevægelse, derimod kun få i Vesteramtet (se kort 2). Der kan endvidere konstateres en sammenhæng mellem sognefogdernes og sogneboernes politiske stillingtagen. Hvor sognefogden stod i Den slesvigske Forening, havde denne som regel forholdsvis stor medlemstilslutning, ligesom der omvendt var mange sammenfald mellem "sogneopstandene« og den stedlige sognefogeds medlemskab af Sognefogedforeningen. Dette peger på sognefogderne som en central faktor for meningsdannelsen i sognene. Til disse prestigefyldte poster udpegede amtmanden i reglen en af de største og mest velansete gårdmænd, d.v.s. de naturlige ledere i landbosamfundet. Sognefogden var således på én gang bondestandens lokale top og statsmagtens stedlige repræsentant, og i en konflikt mellem bønder og embedsmænd kunne han nemt ende $i$ et dilemma mellem sin rolle som bondestandens lokale leder og sin loyalitet over for embedsmændene. Et sådant konfliktstof fandtes i rigt mål i Haderslev Østeramt med den standende strid om afløsningen af tienden og opløsningen af den fælles kirkekasse; en strid, hvor Den slesvigske Forening engagerede sig stærkt på bøndernes side. I et vist omfang kan partidannelsen blandt sognefogderne sikkert tages som udtryk for to forskellige valg i deres dilemma.

På mødet den 29. marts 1844 vedtog Sognefogedforeningen også at indgive en adresse til kongen. Den blev dog noget forsinket og offentliggjordes først $\mathrm{i}$ begyndelsen af juni. ${ }^{13}$ Heri erklærede sognefogderne deres fulde ulfredshed med kongens foreløbige paiınt af 29. marts 1844 , hvorefter det danske sprog kun måtte bruges i stænderne af deputerede, som var ude af stand til at udtrykke sig på tysk - og dermed ikke af Peter Hiort Lorenzen. Patentet førte til skarpe reaktioner fra Den slesvigske Forening, der protesterede til kongen og opfordrede de dansktalencu stænderdeputerede til at nedlægge dere, mandater, hvilket også skete. Drivkraften heri var Peter Hiort Lorenzen, men han og Laurids Skau overvurderede bøndernes vilje til protest, og regeringen svarede med at sætte Den slesvigske Forening under tiltale. Først i januar 1845 blev tiltalen på kongens bestemmelse frafaldet. ${ }^{14}$

I denne situation, hvor Den slesvigske Forening mere end nogensinde måtte tage sig ud som "fredsforstyrrer ", fremstod Sognefogedforeningen som kongens og regeringens taknemmelige og tro støtte. Med afsky for partiånden og med skarp afstandtagen til »de overspændte danskes indblanding i vore indre anliggender« og "propa- 
ganda « søgte sognefogderne at indtage en holdning i sprogkonflikten, der tog hensyn til begge sprog. De fandt det helt rigtigt, at stændernes forretningssprog var tysk, men også retfærdigt, at patentet gav tyskukyndige stænderdeputerede ret til at tale dansk. Ligeledes var det positivt, at sprogreskriptet fra 1840 havde indfort dansk forvaltningssprog, men retssproget måtte godt være forblevet tysk.

Kongens lokale repræsentant, helstatsmanden amtmand Fr. Johannsen, blev også taget i forsvar af Sognefogedforeningen, der overrakte ham en tillidsadresse. ${ }^{15}$ Foreningen søgte også at lægge bånd på talerne på Skamlingsbanken. Efter mødet her den 4. juli 1844 indgav sognefogderne den 25 . juli en adresse til stænderforsamlingen i Slesvig med bøn om »at den høje stænderforsamling vil udvirke, at den sprogstrid, som i den senere tid er opkommet mellem vore tyske og danske brødre på den bedste måde kunne blive nedlagt «. Underskriverne fandt det i sin orden, at Skamlingsbankefesterne udtrykte taknemmelighed for sprogreskriptet fra 1840, "men når høje herrer indfinder sig der og ved deres taler udstrør tvedragtens sæd mellem hertugdømmets fredelige befolkning «, så måtte de bede stænderforsamlingen om at »udvirke at der på de fremtidige Skamlingsfester ikke bliver afholdt taler, som er anstødelige for almuen«. Adressen havde 17 underskrivere, udover sognefogder bl.a. afhopperne fra Den slesvigske Forening, J. Fr. Lorenzen og P. T. Samsøe. ${ }^{16}$

I den fortsatte kamp om kongens gunst gik N. H. Posselt, J. Fr. Lorenzen og E. E. Ladegaard som repræsentanter for foreningen i audiens hos kongen under dennes beseg i begyndelsen af august $1844 .{ }^{17}$ I december fornyedes kontakten til kongen med en ny takadresse. ${ }^{18}$

Lorenzen og Ladegaard - og måske flere af sognefogedkredsen - fik senest i efteråret 1844 kontakt til de slesvig-holstenske kredse i Haderslev by. ${ }^{19}$ De deltog således $i$ en fest $i$ »Bürgerverein« den 24 . oktober 1844 til ære for Haderslevs og Christiansfelds slesvig-holstenske stænderdeputerede, kancelli- og overretssekretær Georg Friedrich Claussen fra Slesvig. Her blev der udbragt et "hoch « for J. Fr. Lorenzen, P. T. Samsøe og de tilstedeværende deltagere $i$ "sogneopstandene" fra Hoptrup, Vilstrup og Aastrup. Også de tre medlemmer af deputationen til kongen fik et »hoch«. J. Fr. Lorenzen holdt en tale på dansk. ${ }^{20}$

Der var således blandt Sognefogedforeningens medlemmer flere, som var parat til at gå videre i slesvig-holstensk retning. Dette samarbejde mellem Haderslev bys slesvig-holstenske borgere og medlemmer af Sognefogedforeningen blev i juli 1845 udgangspunktet for en ny for- 
eningsdannelse, der ikke blot skulle få tilslutning på landet i Haderslev amt og i købstaden, men ud over begge hertugdømmer.

\section{"Den slesvig-holstenske patriotiske Forening " stiftes 1845}

Der var allerede før stiftelsen af Den slesvigske Forening planer fremme om oprettelse af en "Slesvig-Holstensk patriotisk Forening «. I marts 1843 slog Dr. Heiberg, Slesvig, til lyd for en genoplivning af det indsovede "Schleswig-Holsteinische Patriotische Gesellschaft«, der var stiftet $\mathrm{i} 1810 / 12$ på grundlag af oplysningstidens idealer om borgerdyd. I "Lyna" gav redaktør Volquardsen planen sin tilslutning og mente, at foreningen især skulle tage sig af folkeoplysning og tillige omfatte den dansktalende befolkning. ${ }^{21}$ Som afslutning på det slesvig-holstenske folkemøde i juli 1843 i »Hundeklemmen « ved Aabenraa blev der nedsat en komité med medlemmer fra Aabenraa, Haderslev, Tønder, Flensborg, Slesvig, Husum, Egernførde og Rendsborg til at arbejde videre med sagen. ${ }^{22}$ Komitéen mødtes dog først i marts 1844 i Rendsborg, hvor et udkast til vedtægter blev udarbejdet. Formålet skulle være at medvirke til almenvellets og folkedannelsens fremme i hertugdømmerne, især ved at oprette plejeskoler, industriskoler, anstalter for legemsøvelser, herunder våbenøvelser, håndværksskoler, spiseanstalter og arbejdshuse for fattige samt faste og omvandrende læsebiblioteker, ved at forbedre brandvæsnet, ved at udgive folkeskrifter samt ved at fremme fortroligheden med det højtyske sprog. Fra Haderslev sad redaktør Volquardsen fra "Lyna«, dr. Marcus og advokat Stibolt i komitéen. ${ }^{23}$

Det forberedende arbejde forte imidlertid ikke til noget resultat, men tankerne levede dog videre hos de haderslevske komitémedlemmer, og efter endnu godt et års ventetid blev foreningen oprettet. Hvad der ikke lykkedes for repræsentanter for alle hertugdømmernes egne, blev i stedet gennemført på Haderslevegnen af byens ledende slesvig-holstenere i samarbejde med Sognefogedforeningen. Sidstnævntes formand, N. H. Posselt på Sønderskovgård, indkaldte "ligesindede patriotiske mænd «, som var »selvstændige land- og stadbeboere, der deler den anskuelse, foreningen hidind til har lagt for dagen « til at indtræde i Sognefogedforeningen, som dermed skulle omdannes. ${ }^{24}$

Den 7. juli 1845 blev det konstituerende møde i "Den slesvig-holsten- 
ske patriotiske Forening " holdt hos gæstgiver Iversen på Torvet i Haderslev. ${ }^{25}$ Her valgtes en bestyrelse bestående af gårdejer N. H. Posselt som »directeur ", garvermester M. G. Göhlmann fra Haderslev som "vicedirecteur «, gårdejer Joh. Friedr. Lorenzen fra Kestrup som sekretær og gårdejer E. E. Ladegaard, Skærbæk i Hoptrup sogn som kasserer. Der var ialt 29 stiftende medlemmer. Udover Posselt og Ladegaard indtrådte fire andre sognefogder fra Sognefogedforeningen, nemlig C. Iversen fra Fredsted, P. Hansen fra Magstrup, $\mathrm{Cl}$. Petersen Bjerg fra Ødis, J. Jørgensen fra Favstrup og Knud B. Nissen fra Vilstrup. Nok så bemærkelsesværdigt er det imidlertid, at der var otte ud af 15 medlemmer af Sognefogedforeningen, som ikke lod sig optage i Den slesvigholstenske patriotiske Forening - formentlig fordi de som konservative slesvigere fandt den for udpræget slesvig-holstensk. Ved siden af J. F. Lorenzen og C. Iversen var også den tredje udbryder fra Den slesvigske Forening, krovært P. Therkelsen Samsøe, stiftende medlem af den nye forening.

Fremhæves blandt de stiftende medlemmer bor endvidere dr. Marcus i Haderslev, der som medlem af den ovennæunte forberedende komité for en slesvig-holstensk patriotisk forening sandsynligvis var den egentlige initiativtager til foreningen. I hvert fald var det ham, der skrev vedtægterne og siden mange af foreningens petitioner o.l. Men ligesom Peter Hiort Lorenzen og Peter Chr. Koch nøjedes med

\section{Extraordinair Foriamling.}

Sogneioged = Forcuingen lyolter en crtronodis unir Forfanliutg 9lmonagen beut 7. Suli nofff. oun Formibsagen Sit. 10! love 5r. Ssjirftgiver Suerien para Torvet i Saberalles.

Da bene Forening allerebe tioligere har be= fluttet, at ben iffe blot ffulbe beftrae aj Sogues fogoer fra Saterbley 2fmet, men at ogina anbre ligefinbebe patriotiffe Manb funde inbtrixbe $i$ famme, fan opforbres berved alle felvefianbige Enid = ug Strobebucre, ber bele ben 2tuffuelipe, Foreningen libinbtil bar lagt for Danen, at ino= fiitbe fis til bemelote $\mathfrak{T}$ io i frorjamling fur ejter 2umelbelie at lnbe fig optnge $i$ For $=$ eningen og berumft at beeltage $i$ Forbnolingerne. Sunberfuygand ben 25. Suni 1845. N. $\mathfrak{h}$. Pobiclt.
"Den slesvig-holstenske patriotiske Forening" blev grundlagt som en fortsættelse af "Sognefogedforeningen «, der ved omdannelsen fik et bredere medlemsgrundlag. Sognefogedforeningens formand, gårdejer N.H.Posselt pă Sonderskovgård $i$ Frorup sogn, indkaldte $i$ "Lyna" den 2. juli 1845 til det stiftende mode $i$ den nye forening, som han også blev formand for. Det var dog kun knap halvdelen af Sognefogedforeningens medlemmer, som fulgte med over $i$ den nye forening, der udviklede sig mere og mere $i$ slesvig-holstensk retning. 
fra baggrunden at trække i trådene i Den slesvigske Forening og lod nogle fremtrædende bønder stå som ledere udadtil, foretrak den stærkt slesvig-holstensk engagerede læge indtil videre at stå som menigt medlem. ${ }^{26}$ Hensynet til landboerne var givetvis også grunden til, at protokollen førtes på dansk. Andre fremtrædende slesvig-holstenere blandt de første medlemmer fra Haderslev by var næstformanden M. G. Göhlmann, den nye redaktør af »Lyna« M. Schultz, jernstøber Bonnichsen og sadelmagerbrødrene J. C. og J. G. Bungartz. ${ }^{27}$ Af de 14 stiftende medlemmer fra byen var 11 samtidig medlemmer af »Bürgerverein ${ }^{28}{ }^{28}$ Forekomsten af disse overbeviste liberale slesvig-holstenere fra Haderslev blandt stifterne gør det yderst nærliggende at tolke oprettelsen af Den slesvig-holstenske patriotiske Forening som deres forsøg på at bringe de konservative slesvigere og især kredsen omkring Sognefogedforeningen ind under direkte slesvig-holstensk indflydelse.

Foreningen vedkendte sig i sin første vedtægtsparagraf det nære slægtskab til Sognefogedforeningen. Den anden paragraf karakteriserede foreningens målgruppe som "patriotiske, selvstændige mænd af enhver stand, fra land og stad«. Den tredje paragraf fastslog navnet "Den slesvig-holstenske patriotiske Forening«, mens den fjerde angav formålet: "på lovlig måde og med alle til dens rådighed stående tilladte midler at fremme patriotiske anliggender ved fælles forhandlinger og rådslagninger, ved udbredelsen af en passende hensigtsmæssig lekture og ved fælles foretagender indenfor de lovlige skranker, forsåvidt dens kræfter tillader det, for derved at kunne vække og styrke folkets sans for almenvellet «. Endvidere bestemte vedtægterne, at nye medlemmer kunne optages, hvis $2 / 3$ af medlemmerne stemte derfor ved ballotement, og at der skulle afholdes medlemsmøde hvert kvartal. ${ }^{29}$

Stiftelsen af Den slesvig-holstenske patriotiske Forening fandt sted, mens den danske bevægelse var inde $i$ et dødvande efter den forgæves offensiv for det danske sprog i den slesvigske stænderforsamling og myndighedernes lammelse af Den slesvigske Forening. Meddelelsen om oprettelsen vakte derfor bekymring hos den danske bevægelses ledere, $\mathbf{i}$ hvert fald hos Laurids Skau: "Denne efterretning er $\mathbf{i}$ høi grad vigtig og vil blive af uberegnelige følger, eftersom den vil faae alle kræfter og al den hjælp, som vi mangle. Den har eller faaer hele embedsstanden paa sin side, og en stor mængde tydskere, der ere komne herind og tilranet sig mange af de storre gaarde, ville na- 
turligvis træde til. Mange bønder ville af bare forfængelighed løbe med, fordi det er rart at staae i god forstaaelse og nær forbindelse med embedsmændene, og foreningen er saa meget farligere, fordi den er dansk[sproget], saa at det nationale vaaben er os afskaaren imod den. Den opstiller som firma, at den blot vil bevare vore rettigheder, det vil sige, den vil holde paa forbindelsen med Holsteen og udbrede den slesv[ig]-holsteenske statslære som den ene saliggiørende troe, men ingenlunde angribe sproget, men snarere forsvare det. Paa denne maade kan mange bønder rives med, som ikke ane, at foreningen har en reen politisk betydning; thi at holde paa materielle fordele og bevare de indbildte rettigheder, dette vil bønderne naturligviis gjerne. Jeg er fortvivlet over denne operation, og har allerede havt een søvnløs nat med at spekulere paa midler til at værge os med «. ${ }^{30}$

\section{»Den slesvig-holstenske patriotiske Forening «s medlemmer}

Den slesvig-holstenske patriotiske Forening optog i sin femårige levetid 725 medlemmer, der efter optagelsestidspunkt og bopæl fordelte sig således: ${ }^{31}$

\begin{tabular}{l|lll|llllr}
\hline & \multicolumn{3}{|c|}{1845} & \multicolumn{5}{c}{1846} \\
& $7 / 7$ & $4 / 8$ & $6 / 10$ & $9 / 1$ & $3 / 4$ & $7 / 7$ & $24 / 8$ & $5 / 10$ \\
\hline Haderslev by og amt & 29 & 31 & 18 & 13 & 7 & 5 & 2 & 1 \\
Øvrige Nordslesvig & - & - & 66 & 21 & 16 & 2 & 1 & 69 \\
Sydslesvig* & - & - & 2 & - & - & 1 & - & 2 \\
Holsten & - & - & - & - & - & - & - & 86 \\
\hline I alt & 29 & 31 & 86 & 34 & 23 & 8 & 3 & 158 \\
\hline Året i alt & & 146 & & \multicolumn{5}{c}{226} \\
\hline
\end{tabular}

\begin{tabular}{l|rrrll|l}
\hline & \multicolumn{7}{|c|}{1847} & 1848 \\
& $7 / 1$ & $6 / 4$ & $21 / 6$ & $11 / 10$ & $13 / 12$ & $27 / 10$ \\
\hline Haderslev by og amt & 12 & 3 & 5 & 5 & 1 & 15 \\
Ovrige Nordslesvig $^{\text {Sydslesvig* }}$ & 3 & 9 & - & 1 & - & - \\
Holsten $^{163}$ & 57 & - & - & - & - \\
\hline I alt & 57 & - & - & - & - & - \\
\hline Aret i alt & 235 & 69 & 5 & 6 & 1 & 15 \\
\hline
\end{tabular}




\begin{tabular}{|c|c|c|c|c|c|}
\hline & \multicolumn{2}{|c|}{1849} & \multirow{2}{*}{$\begin{array}{l}1850 \\
21 / 1\end{array}$} & \multicolumn{2}{|c|}{$1845-50$} \\
\hline & $15 / 1$ & $17 / 12$ & & Ialt & Pct \\
\hline Haderslev by og amt & 7 & 6 & 9 & 169 & 23 \\
\hline Øvrige Nordslesvig & - & - & - & 188 & 26 \\
\hline Sydslesvig* & - & - & - & 225 & 31 \\
\hline Holsten & - & - & - & 143 & 20 \\
\hline I alt & 7 & 6 & 9 & 725 & 100 \\
\hline Året i alt & \multicolumn{2}{|c|}{13} & 9 & & \\
\hline
\end{tabular}

* Incl. Flensborg.

Den slesvig-holstenske patriotiske Forening var ved stiftelsen en forening for Haderslev amt og by, men fik dog allerede fra efteråret 1845 indmeldelser fra det ovrige Nordslesvig. Imidlertid gik nytilgangen nærmest i stå allerede efter et års virksomhed. Den slesvigske Forening havde tilsvarende haft størstedelen af sin medlemstilgang i lobet af et enkelt år, 1843/44. De nationale foreningers medlemspotentiale i 1840 'ernes Nordslesvig var altså temmelig begrænset, formentlig til et par procent af den voksne mandlige befolkning.

I sommeren 1846 indtraf imidlertid en begivenhed, der påny skulle sætte skub i tilslutningen til Den slesvig-holstenske patriotiske Forening: Kong Christian 8.s "åbne brev" af 8 . juli. Heri afviste kongen den augustenborgske hertugslægts arvekrav og dermed forhåbningen om at få skabt et selvstændigt Slesvig-Holsten ad den vej. Som følge af den vældige protestbølge, det »åbne brev« førte med sig, indtrådte i vinteren 1846/47 hele 393 nye medlemmer. Blandt de 69 nordslesvigere, som meldte sig ind i december 1846, var således 47 borgere fra den hidtil uengagerede Tønder by samt forpagterne fra de augustenborgske ladegårde. Hovedparten af de nye medlemmer kom imidlertid fra Sydslesvig og Holsten og forandrede foreningen fra en altovervejende nordslesvigsk til en generel slesvig-holstensk forening, selv om de nok overvejende var passive støtter. Fra sommeren 1847 var tilgangen atter minimal, og de få lokale nyindtrædelser efter den slesvig-holstenske opstand i marts 1848 ændrede intet herved.

Medlemsskaren var meget spredt (se kort 3). Trods en del tilsyneladende tilfældigheder var der dog visse koncentrationer. Spredt over Haderslev Østeramt fandtes i de fleste sogne 1-5 medlemmer (flest i Vilstrup med 7). Samlet lå tilslutningen her imidlertid langt under Den slesvigske Forening, og i forhold til »sogneopstandene« var den 


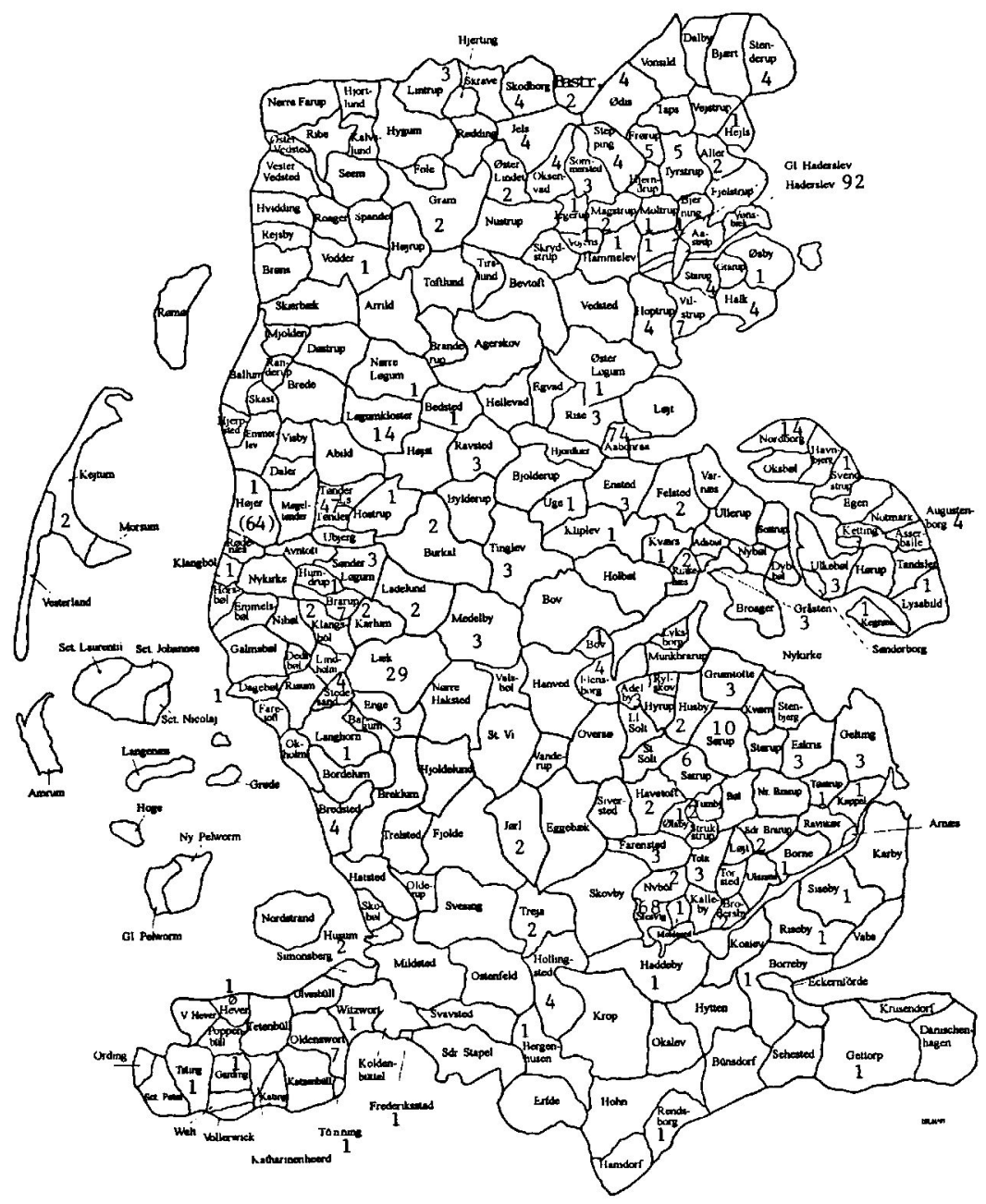

Kort 3: Medlemmer af »Den slesvig-holstenske patriotiske Forening "1845-50 (i hertugdømmet Slesvig).

meget beskeden. ${ }^{32}$ Ligesom over halvdelen af sognefogderne fra Sognefogedforeningen undlod at indmelde sig i Den slesvig-holstenske patriotiske Forening, var der altså langt fra at underskrive en sogneopstand til at melde sig ind i den nye forening. Nok kunne der gå en vej fra slesvigsk konservatisme til slesvig-holstenisme, men den var snarere en smal sti end en bred motorvej! Blandt de mange tilhængere 
af Slesvigs fortsatte beståen som et selvstændigt hertugdømme var Den slesvig-holstenske patriotiske Forening åbenbart hos det store flertal lige så stor en vederstyggelighed som Den slesvigske Forening.

Byerne Haderslev, Aabenraa, Tønder, Slesvig og Rendsborg havde mange medlemmer, mens der ikke fandtes en eneste i Sønderborg og kun et par stykker i Flensborg, Husum, Tønning, Frederiksstad og Egernførde. På tilsvarende vis var der adskillige medlemmer i flækkerne Nordborg og Løgumkloster, men få i Højer, Christiansfeld og Højer - der dog fik en filial i 1849. På landet i Sydslesvig udmærkede Angel sig med forholdsvis mange medlemmer, især i Satrup-Sørup. Fra Læk og omegn kom der ligeledes forholdsvis mange indmeldelser.

I social henseende bejlede Den slesvig-holstenske patriotiske Forening til de selvstændige $\mathrm{i}$ by og på land, og det var også fra disse lag, medlemmerne kom: ${ }^{33}$

\begin{tabular}{|c|c|c|c|c|c|c|c|}
\hline Procent & $\begin{array}{l}\text { Had. } \\
\text { amt }\end{array}$ & $\begin{array}{l}\text { Øvrige } \\
\text { Nordsl. }\end{array}$ & $\begin{array}{l}\text { Nordsl. } \\
\text { i alt }\end{array}$ & $\begin{array}{l}\text { Syd- } \\
\text { slesvig }\end{array}$ & $\begin{array}{l}\text { Hol- } \\
\text { sten }\end{array}$ & I alt & $\begin{array}{l}\text { Den } \\
\text { slesvigske } \\
\text { Forening* }\end{array}$ \\
\hline $\begin{array}{l}\text { Godsejere, propri- } \\
\text { etærer, møllere }\end{array}$ & 6 & 5 & 6 & 8 & 3 & 6 & 1 \\
\hline Godsforpagtere o.l. & 4 & 4 & 4 & 2 & 1 & 3 & - \\
\hline $\begin{array}{l}\text { Kobmænd, fabri- } \\
\text { kanter, redere }\end{array}$ & 11 & 31 & 22 & 13 & 28 & 20 & 1 \\
\hline Liberale erhverv & 4 & 6 & 5 & 13 & 15 & 10 & 1 \\
\hline Embedsmænd & 7 & 3 & 5 & 6 & 7 & 6 & 1 \\
\hline Præster & - & - & - & 1 & - & 0 & 2 \\
\hline Larere & 1 & 2 & 1 & 1 & 3 & 2 & 3 \\
\hline Studenter & - & - & - & 2 & 2 & 1 & 0 \\
\hline Håndværksmestre & 28 & 25 & 27 & 10 & 18 & 20 & 6 \\
\hline $\begin{array}{l}\text { Gårdmæend, } \\
\text { gårdforpagtere }\end{array}$ & 31 & 10 & 20 & 20 & 7 & 17 & 73 \\
\hline $\begin{array}{l}\text { Husmænd, } \\
\text { parcellister }\end{array}$ & - & - & - & 1 & 1 & 0 & 7 \\
\hline Gæstgivere & 4 & 10 & 7 & 2 & 5 & 5 & 2 \\
\hline $\begin{array}{l}\text { Andre og uden } \\
\text { angivelse }\end{array}$ & 5 & 4 & 4 & $20^{* *}$ & 10 & $10^{* * *}$ & 2 \\
\hline I alt & 100 & 100 & 100 & 100 & 100 & 100 & 100 \\
\hline Antal & 169 & 188 & 357 & 225 & 143 & 725 & 484 \\
\hline
\end{tabular}

* Kun medlemmer i Nordslesvig (altovervejende Haderslev amt), ikke kongerigske støttemedlemmer.

** Heraf er formentlig 17-18\% gårdmænd (navnene er knyttet til landsbyer).

*** Heraf er formentlig 5-6 \% gărdmænd. 
Som helhed havde Den slesvig-holstenske patriotiske Forening en bred og varieret tilslutning i over- og middelklassen. Kobmænd, redere og fabrikanter (med et tysk udtryk "Besitzbürgertum «) udgjorde en femtedel, liberale erhvervsudøvere, embedsmænd, præster, studenter og lærere ("Bildungsbürgertum «) næsten lige så meget. En fjerdedel var håndværksmestre og gæstgivere (»Kleinbürgertum«), mens gårdmændene formentlig udgjorde næsten lige så stor en andel. Endelig kom under en tiendedel fra gods- og proprietærgårdsmiljøet.

Sammenlignet hermed havde Den slesvigske Forening en meget ensidig social sammensætning med fire femtedele landmænd, nogle få håndværkere og præster/lærere, mens andre grupper stort set var fraværende. I sit kærneområde i Haderslev amt havde Den slesvigske Forening ca. 350 gårdmænd som medlemmer, mens Den slesvig-holstenske patriotiske Forening her kun havde et halvt hundrede. Laurids Skaus store frygt for Den slesvig-holstenske patriotiske Forening viste sig derfor ret ubegrundet, vel fordi foreningen mod Skaus forventning fremtrådte mere slesvig-holstensk end slesvigsk.

Den slesvig-holstenske patriotiske Forening havde sin største folkelige bredde i Haderslev amt og by, hvor der var forholdsvis flere håndværksmestre, gæstgivere og gårdmænd end $\mathrm{i}$ foreningen som helhed. I det øvrige Nordslesvig var det derimod kun nogle få fremtrædende gårdmænd, som indtrådte, mens tilslutningen i byerne var bredere. I Sydslesvig var der atter en stor andel af gårdmænd, som afspejlede slesvig-holstenismens stærke stilling blandt de velstillede bønder, særlig i Angel. Den store tilslutning fra de liberale erhverv skyldtes især byen Slesvigs mange advokater, hvoraf flere var ledende i den slesvig-holstenske bevægelse, f.eks. C. Heiberg, W. H. Beseler og J. G. Th. Gülich. I Holsten var foreningen mere bypræget, og gårdmænd indtrådte kun sporadisk, især i området omkring Ahrensburg. Besynderligt var det, at der kun indtrådte tre medlemmer fra slesvigholstenismens højborg Kiel.

»Dannevirke « fastslog om de første medlemmer, at det mest var store ejendomsbesiddere, ofte indvandrede sydfra. Rigtigt er det, at ganske mange ejere, forpagtere eller inspektører på de større gårde stod i Den slesvig-holstenske patriotiske Forening. Blandt medlemmerne i Haderslev amt var således forpagter Ahlefeldt på Brødremenighedens Favrvrågård, Thiesen på Sottrup, administrator Steen på Tåbdrup, Vogel på Drenderupgård, H. H. Witzke på Hovgård, Petersen på Olufs- 
kær, Nic. Lorenzen på Refsø, forpagter Feddersen på Vojensgård, Matzen på Tørninggård og inspektør von Krogh på Billeslund. Rigtigt er det ligeledes, at der blandt de nævnte var adskillige indvandrede holstenere og sydslesvigere. ${ }^{34}$ Flertallet af medlemmerne på landet var dog også i Haderslev amt indfødte gårdmænd.

Fra det øvrige nordslesvigske proprietærgårds- og storbondemiljø indtrådte på vesteregnen Justus Meyer på Fårgård, Boy Momsen på Store Tønde, Joh. Friedr. Momsen på Vrågård, Buchardi på Grøngård og Daniel Hinrichsen i Øster Terp. På Aabenraa-Gråstenegnen og på Als var der bred tilslutning fra hertug Christian Augusts forpagtere og venner blandt de mindre godsejere: forpagter Outzen på Ȧrup, P. Jacobsen på Grøngrøft, forpagter Feddersen på Kiding, J. W. Mylord på Ȧrtoft, H.C. Ohlsen på Ladegård, H.C. Richelsen på Buskmose, forpagter Holst på Gråsten, Witzke på Hjortholm, forpagter Andersen på Kegnæsgård, forpagter Dieck på Rønhave, inspektør Maack på Augustenborg samt A. Thomsen på Hjortspringgård. Også i Sydslesvig var der adskillige godsejere blandt medlemmerne, dog ikke ridderskabsmedlemmer fra de store godser i Svans og Dänischwohld, men ejere af mindre godser som Tolkskovby, Freienwillen og Südensee i Angel samt Høgelund, Lütjenhorn, Gaarde og Fresenhagen på egnen omkring Læk. Gårdmandsmedlemmer i Sydslesvig var de to landbrugsfaglige foregangsmænd i Angel, A. Petersen fra Hvidkilde i Tøstrup sogn og Peter Jensen fra Oksager i Husby sogn.

Blandt medlemmerne var der adskillige stænderdeputerede og stændersuppleanter: For Haderslev by advokat P. Gottfriedsen, Haderslev og suppleanten, kancellisekretær Claussen, Slesvig; for Aabenraa by advokat J.G. Th. Gülich, Slesvig; for Tønder advokat W. H. Beseler, Slesvig og suppleanten, købmand J. C. Todsen, Tønder; for 1. landvalgsdistrikt (Haderslev vesteramt) suppleanten, gdr. H. H. Petersen, Nissumgård; for 4. landvalgsdistrikt (Aabenraa amt og en del af Slogs herred) gdr. Thies Hansen Steenholdt, Ravsted og suppleanten, gdr. Hieronymus Petersen, Søst; for 7. landvalgsdistrikt (bl.a. Tønderegnen) gdr. D. Lassen i Brarup og suppleanten, justitiar A. Hansen, Læk; for 9. landvalgsdistrikt (bl.a. med Bov sogn) advokat Rønnenkamp, Flensborg. Dermed var næsten alle slesvig-holstenske stænderdeputerede og -suppleanter fra Nordslesvig medlemmer, og det gav formentlig foreningen en ekstra politisk tyngde. Også i Sydslesvig og Holsten indtrådte adskillige stænderdeputerede og stedfortrædere i Den slesvig-holstenske patriotiske Forening. ${ }^{35}$ 


\section{Organisatoriske forhold}

Den slesvig-holstenske patriotiske Forening lededes indtil 1847 af bønder fra Haderslev amt. I 1846 blev gdr. J. C. Göhlmann, Vonsmose, således kasserer i stedet for gdr. E. E. Ladegaard. I juni 1847 ønskede direktøren gdr. N. H. Posselt imidlertid ikke genvalg. Ȧrsagerne hertil er ukendte, men måske havde foreningens ændrede karakter efter de mange nyindmeldelser af støttemedlemmer sydfra fjernet den for meget fra udgangspunktet i Haderslev amt og Sognefogedforeningen, og måske var Posselt ikke den rigtige til at stå i spidsen for foreningen under den mere radikale kurs, der var fremkaldt efter det "åbne brev«. I hvert fald blev hans afløser dr. Marcus, der var mere udpræget slesvig-holstensk. J. Fr. Lorenzen blev ny vicedirektør efter garver Göhlmann, mens gæstgiver Petersen i Aller afløste Lorenzen som sekretær. Da der i oktober 1848 valgtes ny bestyrelse, blev jernstøber Bonnichsen vicedirektør, boghandler Wieck kasserer og lærer A.P. Willatzen sekretær. Senest fra dette tidspunkt, men i realiteten måske tidligere, var foreningen udelukkende ledet af bymennesker. Det sidste valg i december 1849 ændrede intet herved, kun blev kontrollør Falkenberg sekretær i stedet for Willatzen.

De mange nyindtrædelser $i$ vinteren $1846 / 47$ gjorde en organisatorisk ændring nødvendig. På forslag fra dr. Marcus vedtoges det $\mathrm{i}$ april 1847 at give mulighed for oprettelse af filialforeninger for dem, der boede uden for Haderslev by og amt, såfremt der kunne samles 24 medlemmer. De forskellige filialer skulle sende delegerede til et årligt fællesmøde for alle foreninger, som skiftevis skulle afholdes i Flensborg og Kiel. Det kan anses for ret sikkert, at der allerede før 1848 dannedes filialforeninger i Aabenraa og Rendsborg, mens det er usikkert, om det også er sket $\mathrm{i}$ andre medlemsrige byer som Tønder og Slesvig. ${ }^{36}$ Derimod foreligger der hverken i protokollen eller pressen referater fra fællesmøder, og det er nok et åbent spørgsmål, om den nye struktur overhovedet kom til at fungere.

I slutningen af oktober 1849 dannedes der en slesvig-holstensk patriotisk forening i Højer. Stifterne var toldassistent A. von Krogh, gdr. C. R. Carstensen, lægen dr. H. C. Hansen, gdr. og brændevinsbrænder M.C. Matthiesen, farvermester S.D. Hoeg og købmand H. Feddersen. ${ }^{37}$ De tnsprogede vedtægter fra den 17 . november samm drede foreningens formål som "med alle lovlig tilladte midler at virke for nationalitetens kræftelse, at opretholde den borgerlige ro og or- 
den, og uden hensyn til standen at give enhver ulastelig, patriotisk sindet statsborger lejlighed til ved mundtlig omtale og læsning at forskaffe sig kundskab om politiske tildragelser og andre ting af almindelig interesse, såsom $i$ vigtige anliggender at gøre en almindelig rådslagning lettere mulig“. Medlemmer kunne blive enhver, der var bosat i Højer flække og landsogn eller omegnen, dog ikke mere end en mil fra flækken, også beboere i enklaverne. ${ }^{38}$ Højerforeningen fik ved stiftelsen 34 medlemmer og havde i november $184964 .^{39}$

Højerforeningens stiftelse kom hovedforeningen for øre, og den besluttede at tage kontakt til den. Imidlertid strandede en organisatorisk tilknytning på vedtægtsuoverensstemmelser, idet Højerforeningen ikke ville opkræve kontingent, men kun modtage frivillige medlemsbidrag. Man var dog i Højer villig til uformelt samarbejde, f.eks. om indsamling til invalider. Ellers bestod aktiviteterne dér mest $\mathrm{i}$ von Kroghs dansksprogede foredrag om Slesvig-Holstens historie. ${ }^{40}$

Et problem opstod for Den slesvig-holstenske patriotiske Forening, da "Lyna« ved årsskiftet $1847 / 48$ blev overtaget af Peter Chr. Koch fra "Dannevirke«. I stedet valgte foreningen det meget udbredte, udpræget slesvig-holstenske »Itzehoer Wochenblatt« som sit organ. Blot få måneder senere, efter den slesvig-holstenske opstand, fik Haderslev imidlertid påny et tysksindet, men dansksproget blad. Fra den 6 . maj 1848 og frem til den 10. juli 1850 udkom "Nordslesvigsk Tidende», som meget naturligt blev foreningens organ.

\section{Patriotiske initiativer}

Den slesvig-holstenske patriotiske Forening forstod sig tildels som en efterfølger til det indsovede "Schleswig-Holsteinische Patriotische Gesellschaft «. Som sådan tog foreningen flere skridt til at fremme erhvervslivet på Haderslevegnen.

Allerede på et af foreningens første møder foreslog dr. Marcus, at der skulle afholdes en industriudstilling, hvor håndværkere og industridrivende kunne præsentere deres varer. ${ }^{41}$ Der blev nedsat en komité bestående af forslagsstilleren, garvermester Göhlmann, snedkermester Suchland, jernstøber Petersen, smedemester Claussen samt saddelmagermestrene G. Bungarz og H. Jensen, alle i Haderslev. Komitéen indbød til tegning af bidrag, således at foreningen efter udstillingen kunne købe varerne og udlodde dem til bidragyderne. Blandt bidragyderne bemærkes ud over mange af medlemmerne hertug 
Inbufrie: 2 (usfellung in Saberslebcu.

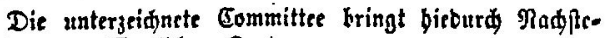
benbed zur öfentliden Sunbe:

1) Die Inbuftrie = Ausjtellung in Saberdleten wirb ben 1flen Snni b. 3. erïfnet unb ben 16ten Suni Nabmittags $6 \mathrm{ubr}$ geílolien werben.

2) शBäbrenb ber genaunten Zrit if bie Rtuftelleng tïglid) Bormittags von 9 bid 12 ubr und Nadmittags bon 3 bis 6 ubr geiffnet.

3) Die Berloojung Ivirb Freitng, ben 19 ten Suni 1846 , fattfinben und biefelbe Mlorgend 9 ubr ibren \&njany nebmen.

4) Die Einlieferungen son Mrbciten milifen fponteften bis gum 26fen Mai b. 3. bejめnfit werben, utto werben vor bem 16 ten bes gennnnten Monats feine (s)rgen= finbe bon ber Sommittee in Empfing gertummen. Die cinzuliefernben (Begenfänbe finb an ben mitunterzrid: treten $\mathfrak{M}$. (3). (S) öblmann ju abreffirelt.

5) Die auswärtigen Serren Alctionaire unb Einfenter non Arbeiten baben, folls fie bie Auditellung bejudent wollen, ibre Eintrittofarten bei bem mitunterjeidune. ten Dr. $M$ arcus in Empjang зи nebmen.

Saberdleben, im Sanuar 1816.
Tubupri=11bptiding i sabcroleb.

Untertegucte Comitee bringer berbeb Julgente til offentlig Suusfiab:

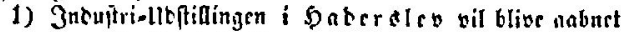
cen 1 ife Guni b. 2 . og futtet ber 16 re 3uni on Eftermitragen floften 6.

2) 3 benabnte zid or llspillingen saglig anbort om Sormibhagen fra fll. 9 til 12 og om ciftermitragru fra Sil. 3 til 6.

3) Bortlobningen vil finte Eteb frrbagen ten 19te Suni b. A., og tage fin Wisgunocle om Morgenen Sil. 9 .

4) Arbeibernes Sublebering ma feneft vare beforget til tan 26be Mai b. K., og ingen (Bjenftand nif blibe motagen af comiten fereno ten 16be $i$ famme Jacneb. Ssienjtanbene, ber intevered, cre at abresjere til mobunbertegnebe $\mathfrak{M}$. (5). (j) jubl$m \mathfrak{a n} \mathbf{n}$.

5) De ubentuges Serrer Ifctionairer og Jutentere af Arbeiber bille, naar be onfle at bcioge usjtillingen, afbente beres Jnbgangobilletter boo mebulibertegnebe Dr. $刃$ arcus.

Saberaleb, i Januar 1846.

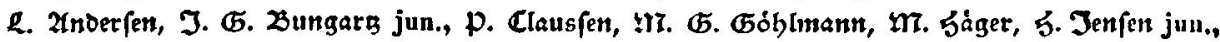

Dr. Marcug, I. Peterfen, w. peterfen, G. P. Peterjen, \&. R. Gudlandt.

Industriudstillingen $i$ Haderslev var et af "Den slesvig-holstenske patriotiske Forening«s mest vellykkede initiativer. Tosproget annonce $i$ "Lyna« 14. januar 1846.

Christian August af Augustenborg, hans hofråd Barth og flere andre af hofstaben samt hans politiske fælle, herredsfoged dr. Momme Steffens fra Nordborg.

Udstillingen fandt sted i første halvdel af juni 1846. Der blev udstillet ialt 565 genstande, de fleste fra håndværkere og industridrivende i Haderslev (bl.a. et fortepiano fra instrumentmager Jacobsen), men der var også adskillige arbejder fra Aabenraa, Christiansfeld og Løgumkloster (bl.a. fra den bekendte hattefabrikation dér). Også længere borte fra kom der genstande, f.eks. fra snedker Hess, blikkenslager Paulsen, paparbejder Schjøtt og drejer Lau i Slesvig, fra Schwartz' fabrik i Neumünster, skræddermester Christiansen i Rendsborg, litograf Kriegsmann og portrætmaler Wassner i Flensborg samt destillatør P. Petersen i Sønderborg. Fra landdistrikterne havde smed Alexander Schmidt i Vilstrup leveret »flere prisbillige arbejder". Komitéen betragtede udstillingen og publikums interesse som en succes.

Mange af Haderslevs håndværkere var også tilfredse og overrakte initiativtageren dr. Marcus en sølvpokal som tak for hans indsats. Ved overrækkelsen, der skete ved en fest $i$ »Bürgerverein « $i$ september 1846, blev der bl.a. udbragt skåler for dr. Marcus, "fædrelandet Slesvig-Holsten «, for »Den slesvig-holstenske patriotiske Forening", for hertugen af Augustenborg og prinsen af Nør, redaktør Th. Olshausen fra Kiel og herredsfoged Kier i Haderslev. Til slut blev der skålet: "For 
freden, men ikke for en slavisk fred; ingen kan beholde fred længere, end naboen vil«. Som skålerne for augustenborgerne skal denne sidste skål tolkes som en protest mod kongens »åbne brev« fra juli måned.

Af »Lyna «s fremstilling fornemmes således, at det med industriudstillingen var lykkedes slesvig-holstenerne at vinde yderligere tilhængere blandt Haderslevs håndværkere. I hvert fald ville dr. Marcus gentage successen med en ny udstilling i 1848. I oktober $1847 \mathrm{blev}$ der nedsat en komité, men på grund af de dramatiske begivenheder i revolutionsåret kunne udstillingen ikke gennemføres.

Også landboerne blev tilgodeset ved foreningens patriotiske virksomhed. Formanden, sognefoged Posselt fra Frørup, foreslog i januar 1846, at der samme sommer skulle afholdes dyrskue i Haderslevs omegn. ${ }^{42}$ Der var heller ikke her langt fra tanke til handling. En komité bestående af landmændene Boy Jürgensen fra Stubbæk, Hinsch fra Olufskær, Holst fra Frørup, Göhlmann på Vonsmose og Ross på Rønhøjgård blev nedsat, og i april fremlagde den en dyrskueplan. Dyrskuet, som blev det første på Haderslevegnen og formentlig i Nordslesvig i det hele taget, blev afholdt på Erlev banke ved Haderslev den 15. juni 1846 og var efter "Lyna« at dømme en udpræget succes: "Denne skønne fest, der bivånedes af ca. 10000 mennesker, iblandt hvilke der herskede den mest uskrømtede munterhed, vil længe leve i vort minde ${ }^{43}$ Der udstilledes heste (10 hingste, 22 følhopper og 2 ungheste), hornkvæg (11 tyre, 28 malkekøer og et par kvier), 5 får og 3 svin. Til de bedste dyr blev der uddelt præmier på tilsammen 300 rigsdaler courant.

Det landbrugsfaglige var imidlertid kun en del af formålet. Dyrskuet var lige så meget, måske endnu mere, en folkefest. Da præmierne var uddelt, sørgede de slesvig-holstenske sangkor (»Liedertafel «) fra Haderslev og Aabenraa sammen med harmonimusikken for underholdningen. Derefter blev der afholdt festmåltid i teltet for omtrent 500 mennesker, der udover måltidet kunne nyde "de interessante toaster «. Rækken indledtes traditionen tro med en skål for kong Christian 8., men det var med tilføjelsen "vor elskede landsfyrste«, altså som hertug for Slesvig og Holsten mere end som dansk konge. Dernæst redegjorde jernstøber Bonnichsen for Den slesvig-holstenske patriotiske Forenings virksomhed og fremhævede i den forbindelse: »Foreningen kalder sig den patriotiske og dens medlemmer må følgelig være patrioter, og hvad forstår man vel under patriot? Dog vel 
den, der nærer den inderligste, højmodigste, mest levende kærlighed til sit fædreland (og til hvilket fædreland, siger navnet) og tillige klart erkender, at det almindelige velvære er den sikreste borgen, den eneste faste grundvold for enhver enkelts velvære». For Bonnichsen var genstanden for patriotismen altså Slesvig-Holsten og ikke den dansktyske helstat, som ellers symbolsk var fremhævet med flagene ved indgangen med de slesvigske og holstenske faner og Dannebrog. Men måske var denne flagopstilling mere af nød end overbevisning; den blå-hvid-røde slesvig-holstenske »landsfane« var nemlig blevet forbudt i 1845.

Endvidere holdtes skåltaler for dyrskuets arrangører, staden Haderslev, "vort nedarvede fyrstehus og isærdeleshed for Hans Durchlaucht hertugen af Augustenborg", embedsstanden, "vort elskede fødeland Slesvig-Holsten “ (både på dansk og tysk), for enigheden mellem borgere og bønder og for bondestandens oplysning. Sidstnævnte skål udbragtes af foreningens sekretær, J. Fr. Lorenzen, der opfordrede folk til at læse fædrelandshistorien. Det havde han selv gjort og erfaret, "at slesvig-holstenernes anskuelse efter hans overbevisning endnu aldrig var modbevist, hvorfor han også bragte denne sin hyldning «. Efter sit korte medlemskab af Den slesvigske Forening og sin konservativt betonede slesvigske protest imod "daniseringen « havde Lorenzen altså nu fundet sin plads i de bevidste slesvig-holsteneres rækker. Efter denne og de andre dyrskueskåltaler at dømme var Den slesvig-holstenske patriotiske Forening godt i færd med at glide fra sit konservative, slesvigske udgangspunkt i "sogneopstandene og Sognefogedforeningen over mod en nordslesvigsk variant af slesvig-holstenismen.

Åbenbart veltilfreds med forløbet afholdt foreningen påny et dyrskue på Erlev banke den 5. juli 1847.44 Der var ifølge »Lyna« udstillet flere dyr end året før, og der var lidt flere tilskuere, nemlig 10-12000. Dyrskuet forløb tilsyneladende efter helt det samme mønster som i $1846 .{ }^{45}$

Med industriudstilling og dyrskuer havde Den slesvig-holstenske patriotiske Forening gennemført aktiviteter for to af foreningens vigtigste medlemsgrupper. Et tredje patriotisk foretagende havde bud til endnu bredere kredse, nemlig forsøget på oprettelse af sparekasser, $\mathrm{i}$ første række i Haderslev amt. Det blev foreslået af Posselt i juli 1846. Planen var, at der skulle oprettes sparekasser i hvert sogn. Formålet skulle dels være wat give de fattigere og uformuendere klasser af 
landboere, fornemmelig tjenestefolk, daglønnere, svende, lærlinge o.s.v. lejlighed til at gøre det, hvad de har fortjent og opsparet, rentebringende uden frygt for tab, og derved forhindre, at de ikke letsindig bortødsler eller ved udlån til uvederhæftige folk tilsætter det, de har erhvervet", dels "at komme uformuende folk pa landet til hjæelp i pengeforlegenhed med små lån, og at forhindre, at de ikke gøres modløse og uvirksomme med pantsættelse af deres sager og ved at hjemfalde til ågerkarle«. ${ }^{46}$

Imidlertid er der intet, som tyder på, at dette socialt bevidste initiativ kronedes med held, for der blev først oprettet sparekasser i Haderslev amt efter $1850 .{ }^{47} \mathrm{Næv}$ nes kan dog, at medlemmer af foreningen som enkeltpersoner var fremtrædende i sparekassedannelsen - to sydligere egne af Nordslesvig. Boy Momsen på Store Tønde var

.. initiativtager til Hostrup Sogns Sparekasse i 1844, og køb. . . . . Fr. Ahlmann i Gråsten og flere forpagtere på de gråstenske . A.ur var fremtrædende i Spare- og Lånekassen for Gråsten og Omegn fra 1847. Også slesvig-holstensk indstillede uden for foreningen som f.eks. møller C. H. Clausen i Broager var virksomme for oprettelsen af sparekasser. Det tidlige slesvig-holstenske engagement i sparekassesagen viser alt $i$ alt hen til et betydeligt islæt af lokalt fremtrædende matadorer og iværksættere i den nordslesvigske slesvig-holstenisme. ${ }^{48}$

\section{Politiske petitioner og deputationer 1845-47}

Ved siden af den patriotiske virksomhed havde det politiske arbejde fra begyndelsen en stor betydning, som med tiden voksede sig endnu større. De fleste politiske initiativer blev taget i samvirke med grupper i Holsten og Sydslesvig.

Den første politiske mærkesag blev indførelsen af almindelig værnepligt. ${ }^{49} \mathrm{I}$ oktober 1845 blev gårdejerne S. Holst fra Frørup og Joh. Chr. Göhlmann fra Vonsmose sendt som foreningens deputerede til et møde herom i Neumünster. Her traf de sammen med henimod 200 landmænd fra andre egne af hertugdømmerne, der var utilfredse med, at værnepligten alene hvilede på bondestanden, og med det militære straffesystem. På mødet vedtoges at sende en deputation og en petition til kongen. Petitionen fik ialt 35.337 underskrifter, heraf de 13.182 fra Slesvig. Seksmandsdeputationen, som overrakte petitionen til kongen i december 1845, havde bl.a. J. Fr. Lorenzen som medlem. 
Han talte med kongen om stemningen i Nordslesvig og Den slesvigholstenske patriotiske Forening. Ifølge kongens dagbøger forsikrede han, at "dens hensigt ikke var fiendtlig mod den nord schleswigske", d.v.s. mod Den slesvigske Forening, hvilket turde være en sandhed med modifikationer. ${ }^{50}$ Petitionens onske om almindelig værnepligt blev ikke taget til følge, men Den slesvig-holstenske patriotiske Forening havde fået vist, at Den slesvigske Forening ikke var ene om at tage sig af bondestandens sociale og politiske krav.

Samtidig med værnepligtsagen engagerede Den slesvig-holstenske patriotiske Forening sig i den hede diskussion om jernbaneplanerne, som for mange havde nationalpolitiske undertoner. ${ }^{51}$ Danskorienterede købmænd i Flensborg og dansksindede i Nordslesvig støttede således altovervejende en tværbane fra Flensborg over Husum til Tønning for at fremme transitten mellem Østersø og Vesterhav uden om Hamborg. Slesvig-holsternerne ønskede derimod at styrke de nordsydgående forbindelser ved en forlængelse nordpå til Flensborg af det holstenske jernbanenet Altona-Elmshorn-Neumünster-Kiel, Elmshorn-Glückstadt og Neumünster-Rendsborg, som netop var blevet åbnet 1844-45. Den slesvig-holstenske patriotiske Forening fulgte på forslag af dr. Marcus ikke overraskende dette sidste spor i sin petition til kongen. Foreningen anså en direkte og umiddelbar forbindelse med Hamborgs verdensmarked for en absolut nødvendighed for Nordslesvig, "thi Hamborg er netop det sted, hvor vi altid og under alle konjunkturer kan afsætte vore produkter, hvilke de end er, til de højst mulige priser«. Foreningen ønskede derfor ikke alene en forlængelse til Flensborg, men tillige en yderligere udbygning nordpå over Aabenraa og Haderslev til Aarøsund. En sådan længdebane ville bringe større fordele end tværbanen, som foreningen på den anden side dog ikke ville frakende sin berettigelse. Som bekendt kom der imidlertid til at gå to årtier, før Nordslesvig fik sin første jernbane.

Samvirket med holstenske og sydslesvigske politikere fortsatte i 1846. Foreningen vedtog at sende gårdejerne J. Fr. Lorenzen og C. Ross som repræsentanter til en petitionsforsamling i Neumünster den 20. juli. ${ }^{52}$ Forsamlingen lå $\mathrm{i}$ forlængelse af holstenske og sydslesvigske bondepolitikeres arbejde for almindelig værnepligt og havde til hensigt at koordinere indsendelsen af petitioner til dette års stænderforsamling. Petitionerne skulle handle om almindelig værnepligt, kommunalreformer for by og land, trykkefrihed, afskaffelse af kopskatten, overdragelse af jagtretten til grundejerne, en ny 
matrikel uden dermed forbundne skatteforhøjelser, en vandafledningslov, bedre forhold for åremålsforpagterne på de adelige godser, reformer i skolevæsnet og forbedringer for lærerne, en mere overskuelig inddeling af administrationsdistrikterne og folkelig deltagelse i retsplejen.

"Lyna« savnede et krav om forening af de slesvigske og holstenske stænder, og heller ikke andre slesvig-holstenske mærkesager forekom i oplægget til petitionerne. Den kreds, der stod bag, var da heller ikke de ledende nationalliberale i den slesvig-holstenske bevægelse, men bondepolitikere, der mere interesserede sig for forbedringer for bondestanden end for nationalpolitik, og som tillige gik ind for demokratiske krav som trykkefrihed. Det vidner om Den slesvig-holstenske patriotiske Forenings oprindeligt stærke forankring $\mathrm{i}$ bondestanden, at den $\mathrm{i}$ sit første år prioriterede disse kontakter til varetagelse af bøndernes interesser så højt.

Heri skete der imidlertid snart en forandring. Endnu før petitionsforsamlingen i Neumünster var afholdt - hvis den nogensinde blev det - var situationen med ét ændret for den nordslesvigske hjemmetyskhed og den slesvig-holstenske bevægelse i det hele taget. Som nævnt udsendte kong Christian 8. den 8. juli 1846 sit »åbne brev" med afvisningen af den augustenborgske hertugslægts arvekrav på hertugdømmerne ved den oldenborgske kongeslægts snarligt forventede uddøen på mandssiden. Samtidig forsikrede kongen i det åbne brev, at han hverken ville træde hertugdømmet Slesvig dets selvstændighed for nær eller forandre dets forhold til Holsten. ${ }^{53}$

Det åbne brev stillede Den slesvig-holstenske patriotiske Forening $i$ en ganske vanskelig position. Sluttede den sig til den storm af protester, som rejste sig mod det åbne brev, måtte foreningen i det mindste regne med at tabe til Den slesvigske Forening i konkurrencen om kongens gunst. Sandsynligvis risikerede foreningen tillige at blive sat under anklage af den enevældige statsmagt, der foranlediget af protesterne generelt strammede vilkårene for den slesvig-holstenske bevægelse. Dertil kom, at foreningen ved en skarp protest nemt kunne ende $i$ den samme folkelige isolation som tidligere Den slesvigske Forening, der i 1844 havde protesteret så heftigt imod kongens forordning om sproget i de slesvigske stænder, at den havde udfordret bondestandens traditionelle kongetroskab og fået folkestemningen imod sig. Navnlig kongens understregning af at ville respektere status quo i Slesvigs statsretslige stilling mellem kongeriget og Holsten måtte 
tilfredsstille det betydelige element af konservative slesvigere, som foreningen vel stadig søgte at appellere til eller $\mathrm{i}$ hvert fald nødigt ville støde fra sig.

Først efter $1 \frac{1}{2}$ måneds betænkningstid mødtes foreningen $\gg \mathbf{i}$ anledning af de senere tildragelser«. Løsningen blev en petition til kongen, som kun indirekte udtrykte Den slesvig-holstenske patriotiske Forenings utilfredshed med det åbne brev. I stedet for at vende sig mod det åbne brev valgte man defensivt at polemisere mod takadressen fra "den såkaldte slesvigske forening « ${ }^{54}$ Den slesvig-holstenske patriotiske Forening bestred her, at modparten udtalte sig på den nordslesvigske befolknings vegne. Den slesvigske Forening var nemlig "aldeles betydningsløs" og ledet enten af indvandrede nordfra eller folk, som lønnedes af et politisk parti i Danmark, der ville blande sig i Slesvigs anliggender. Kongen blev mindet om, at Den slesvigske Forening kun var sluppet fri for straf ved kongens benådning, og der blev henvist til "sogneopstandene«. Det var ikke hensigten med adressen at bryde forbuddet mod offentlig diskussion af det åbne brev, men man erklærede dog: »Kun så meget må vi sige til sandhedens fremme, at en almindelig glæde, hvorom takadressen taler, ingenlunde er bemærket af os ...«.

Adressen beskæftigede sig også med de sproglige forhold. Den benægtede, at en undertrykkelse af det danske sprog fandt sted og slog til lyd for oget kendskab til tysk: "Rigtignok elsker vi det danske sprog, den egentlige bondestands modersmål i Nordslesvig, men vi indser dog dag for dag tydeligere, at det også er blevet nødvendigt for os, at lære det tyske sprog, thi som beboere af et grænseland må vi nødvendig søge at forskaffe os kundskab i det tyske sprog, da alle vore handelsforbindelser viser os sydpå, da vi ønsker at skride frem med tidens fordringer og da den $\mathrm{i}$ århundreder bestående nøje og uopløselige forbindelse med hertugdømmet Holsten er blevet os kær og dyrebar«. Afslutningsvis frabad Den slesvig-holstenske patriotiske Forening sig indblanding i slesvigske anliggender fra kongeriget, især fra stænderforsamlingen i Roskilde. Ikke alle medlemmer var til stede, da adressen blev vedtaget, men i hvert fald fra tilhængerne i Løgumkloster var der opbakning og tak. ${ }^{55}$

De forsigtige formuleringer og understregningen af det slesvigske frem for det slesvig-holstenske (som der næppe længere var reel dækning for) hindrede foreløbig indgreb mod foreningen fra regeringsside. Men Den slesvig-holstenske patriotiske Forening kom tæt på. I 
marts 1847 drøftede man i regeringskredse at forbyde såvel Den slesvig-holstenske patriotiske Forening som Den slesvigske Forening, men det afviste kongen. ${ }^{56}$ I maj 1847 fik Den slesvig-holstenske patriotiske Forening af amtmand Fr. Johannsen besked på at indlevere sin protokol til gennemsyn, men det gav ikke anledning til anklage eller andre sanktioner. ${ }^{57}$

Det lykkedes således Den slesvig-holstenske patriotiske Forening at styre uden om de værste skær. Som nævnt fik den efter det åbne brev oven i købet en stærk nytilgang af medlemmer fra Sydslesvig og Holsten, mens der omvendt var stagnation i Nordslesvig (bortset fra Tønder). Sammen med formandsskiftet fra Posselt til dr. Marcus svækkede denne nytilgang sydfra imidlertid yderligere foreningens forankring i den konservative nordslesvigske bondestand til fordel for en mere radikal, nationalliberal og bydomineret slesvig-holstenisme.

\section{»Den slesvig-holstenske patriotiske Forening « 1848-50}

Denne tendens slog fuldt igennem efter den slesvig-holstenske opstand i marts $1848 .{ }^{58}$ Man kunne tillige have forventet, at opstanden straks gav Den slesvig-holstenske patriotiske Forening ny vind i sejlene og etablerede den som den fælles organisation for tilhængere af den slesvig-holstenske sag i begge hertugdømmer. Det blev ikke tilfældet. Som det allerede fremgik af medlemsudviklingen, var nytilgangen yderst beskeden og rent lokal, og de samme ord kan i det hele taget karakterisere foreningens virke i krigsårene 1848-50.

Den slesvig-holstenske patriotiske Forening spillede således slet ingen rolle i det »varme forår« 1848 . Her var scenen snarere den haderslevske »Bürgerverein «. Først den 27. oktober $1848 \mathrm{blev}$ der holdt et møde i Den slesvig-holstenske patriotiske Forening. Her redegjorde formanden dr. Marcus for begivenhederne siden krigens udbrud og for den nye og farefulde situation, der var indtrådt for slesvig-holstenerne, efter at Danmark og Preussen havde indgået en våbenhvile $\mathbf{i}$ Malmø den 26. august. Aftalen indebar, at den provisoriske slesvigholstenske opstandsregering skulle træde tilbage til fordel for en dansk-slesvig-holstensk fællesregering, hvilket skete 21.-22. oktober. Den slesvig-holstenske patriotiske Forening vedtog i den anledning en takadresse til den provisoriske regering: »De, højtærede herrer, har 
under Deres hæderlige regering intet øjeblik manglet at retfærdiggøre den til Dem fattede ubetingede tillid, De har meget mere i de vanskelige forhold og de mest forviklede stillinger forstået at forsvare Slesvig-Holstens sag således, at fædrelandets tak til evige tider $\mathbf{i}$ vor histories annaler vil blive Dem opbevaret «. ${ }^{59}$

På samme tid var der røster fremme om en deling af hertugdømmet Slesvig mellem kongeriget Danmark og et selvstændigt SlesvigHolsten. En sådan tanke måtte selvsagt vække den allerstørste modstand blandt slesvig-holstenerne på Haderslevegnen, som i givet fald måtte imødese en indlemmelse i Danmark. Derfor vedtog Den slesvig-holstenske patriotiske Forening i samme møde tillige en adresse til den tyske nationalforsamling i Frankfurt med en energisk protest mod delingstankerne: »Høje Forsamling! På Dem er Nordslesvigs øjne rettet i dette øjeblik. Vi har den tillid til Dem, at De, med hertugdømmerne Slesvig-Holstens retstilstand $i$ tankerne, aldrig og aldrig mere vil indvillige $i$ en forandring, som, hvis den skulle blive til sandhed, vil medføre de bedrøveligste følger. For Den slesvig-holstenske patriotiske Forening, der blandt sine medlemmer tæller et stort antal i Nordslesvig bosiddende landboere med grundejendom, er der under de herskende omstændigheder ingen anden udvej, end hermed at protestere på det højtideligste imod enhver deling af landet, da det, også bortset fra retten, er $\mathrm{i}$ det nordlige Slesvigs interesse, under alle omstændigheder at dele skæbne med det øvrige Slesvig-Holsten«. Adressen var underskrevet af direktionens medlemmer. ${ }^{60}$

Den slesvig-holstenske revolution var ikke kun en national opstand vendt mod Danmark, men især i Holsten tillige en stærk bevægelse for frihed og demokrati. Derfor beklagede en skribent fra Aabenraa i "Nordslesvigsk Tidende" i november 1848, at Den slesvig-holstenske patriotiske Forening og Haderslevs "Bürgerverein « ikke havde deltaget $\mathbf{i}$ det stiftende møde $\mathbf{i}$ "Vereinigte Volks-Vereine in SchleswigHolstein « i Neumünster, hvor bl.a. borgerforeningen i Aabenraa havde været repræsenteret. Udeblivelsen skyldes dog næppe ligegyldighed, men snarere en skepsis mod slesvig-holstenismens demokratiske venstrefløj under Th. Olshausens ledelse, der gik i republikansk retning. ${ }^{61}$

Omkring årsskiftet 1848/49 forlød det, at en kommende fred mellem Danmark og Tyskland ville betyde en adskillelse af Slesvig og Holsten. Mod denne udsigt blev der overalt i hertugdømmerne fra 
Under Treărskrigen holdt "Den slesvig-holstenske patriotiske Forening "kun fa møder, og der maitte et laserbrev til, for formanden dr. Marcus med denne annonce $i$ »Nordslesvigsk Tidende " den 10. december 1849 indkaldte til generalforsamling.

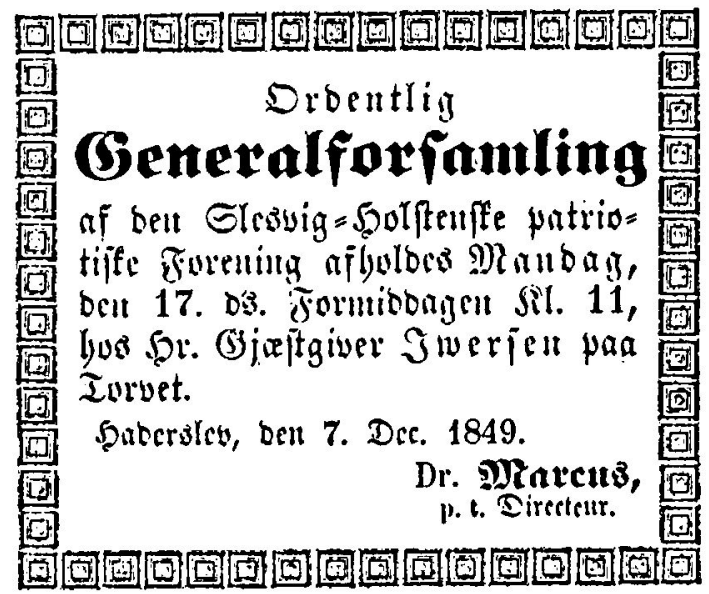

slesvig-holstensk side sat en række masseadresser i cirkulation. Også Den slesvig-holstenske patriotiske Forening engagerede sig heri og besluttede på sit møde den 15. januar at protestere til den tyske centralmagt i Frankfurt. Petitionen blev sendt den 22. januar 1849 af direktionen på vegne af foreningens 660 medlemmer. Heri hed det: »Bliver en sådan tilstand virkeliggjort ved den endelige fredsslutning, så må Slesvig med sin isolerede, d.v.s. fra Holsten adskilte, stilling med absolut nødvendighed $\mathrm{i}$ tidens løb tilfalde danskheden, for det vil ikke være stærkt nok til varigt at yde den nødvendige modstand for at modstå fortsatte danske overgreb; vor martsrejsning, krigens lidelser og klager. de vil være båret til ingen nytte, Tyskland ville med et ord være gået forgæves ind $\mathrm{i}$ krigen ${ }^{62}$

Derpå gik der næsten et år, før der igen blev afholdt møde. Den 5. december 1849 opfordrede »et medlem af foreningen « $i$ »Nordslesvigsk Tidende« bestyrelsen til at holde møde med medlemmerne, og det skete straks efter, den 17. december. Her forklarede dr. Marcus, at krigen længe havde forhindret et møde. ${ }^{63}$ Set fra et hjemmetysk synspunkt var der da heller ikke megen opmuntring at hente i krigens gang siden sommeren 1849. Den slesvig-holstenske hær havde lidt nederlag ved Fredericia den 6. juli, og Preussen havde påny indgået en våbenhvile med Danmark udenom slesvig-holstenerne, denne gang oven i købet med en svensk-norsk besættelse af Nordslesvig og en blandet danskpreussisk-engelsk bestyrelseskommission for Slesvig.

Det energiske danske medlem af bestyrelseskommissionen, Frede- 
rik Ferdinand Tillisch, havde oven i købet om en genoptagelse af krigen udtalt, sat hele befolkningen $i$ hertugdømmet Slesvig ville gives til pris for den grusomste behandling ved den slesvig-holstenske armés indrykken i hertugdømmet Slesvig «. Imod denne ytring iværksatte Den slesvig-holstenske patriotiske Forening på mødet den 17. december 1849 en protestadresse, som sendtes til det slesvig-holstenske statholderskab i Kiel. Denne gang var det ikke kun direktionen, som skrev under, men 439 borgere og indbyggere i Haderslev, 27 beboere i Christiansfeld samt 109 mænd fra amtets landdistrikter - som efter herredsfoged Thomsens udsagn »næsten udelukkende hører til de største og større gårdbesiddere i dette amt «. Dermed havde protesten fra Den slesvig-holstenske patriotiske Forening fået betydelig tilslutning også udenfor medlemskredsen. ${ }^{64}$

Foreningen samledes påny den 21. januar 1850 - igen i en kritis ${ }^{1}$. situation for slesvig-holstenerne. Man henvendte sig atter til det sle vig-holstenske statholderskab over Holsten med bøn om, at dette ville overtage magten også i Slesvig. Til at overrække adressen blev der valgt en deputation bestående af gårdejerne Fuglsang fra Skodborg og E. Holst fra Frørup. ${ }^{65}$

Ud over at afsende adresser koncentrerede Den slesvig-holstenske patriotiske Forening sin virksomhed i krigsårene om at pleje de slesvig-holstenske soldater. For de døde blev der i december 1849 foreslået at rejse monumenter i Christiansfeld og Haderslev, og en komité blev nedsat, men med uvist resultat. Ligeledes blev der i januar 1850 dannet en komité til at forestå en indsamling til invaliderede soldater.

\section{Afslutning}

Indsamlingen til de invalide blev formentlig Den slesvig-holstenske patriotiske Forenings sidste initiativ. Hverken protokol eller presse har mere at berette om dens videre virke - endsige om den opløsning, som blev den uundgåelige følge af Treårskrigens endelige udfald efter de danske sejre over slesvig-holstenerne ved Isted 25. juli og Frederiksstad 4. oktober 1850 og genetableringen af den danske konges styre $\mathrm{i}$ hele Slesvig. Forst efter 1864 blev der påny udfoldelsesmuligheder for tysk foreningsliv i Nordslesvig - og så gik der endda et kvart århundrede, før Den slesvig-holstenske patriotiske Forening i 1890 fik sin efterfølger som samlingspunkt for hjemmetyskheden med oprettelsen af "Den tyske forening for det nordlige Slesvig « ${ }^{66}$ Som 
navnet antyder, var det da ikke længere onsket om et forenet og uafhængigt Slesvig-Holsten, medlemmerne samlede sig om, men troskaben mod kejseren og det nye tyske rige.

\section{HENVISNINGER}

1. Den danske bevægelses frembrud skildres grundigt på grundlag af samtidige breve hos Peter Lauridsen: $\mathrm{Da}$ Senderjylland vaagnede, I-VIII, Kbh. 1909-22. Nyere synspunkter og resultater findes hos Anders Pontoppidan Thyssen: Vækkelse, kirkefornyelse og nationalitetskamp i Sønderjylland 1815-1850, Aabenraa 1977 samt hos Hans Schultz Hansen: Den danske bevægelse i Sonderjylland ca. 18381850. I: Historie, ny række 18:3, 1990, s. 353-395. Tiden behandles generelt af Knud Fabricius i Sonderiyllands Historie, IV, Kbh. u. år.

2. Lyna 3.12.1843.

3. H. R. Hiort-Lorenzen: Den slesvigske Forening. Sønderjyske Årbøger 1890 , s. $160,167$.

4. Lyna 24.12 .1843 .

5. Lyna 27. og 31.1., 21.2., 6., 9. og 23.3., 25.5., 26.6. og 3.7.1844. 17.2.1844 endvidere uddybende erklæring fra Hoptrup.

6. Der er ikke sat titler på underskriverne. I Vilstrup sogn betegnes underskriverne dog som landbesiddere, i Bjerning som grundbesiddere, i Skodborg, Maugstrup og Stepping som lodsejere. En sammenligning med stændervalglisterne viser et stort antal sammenfald.

7. Dannevirke 30.12.1843, 24. og 31.1. samt 22.6.1844.

8. Derimod vides med sikkerhed, at hertugen af Augustenborg via sin politiske agent, pastor Jürgen Brag i Adsbøl, stod bag en petition til kong Christian 8. hovedsagelig fra Als og Sundeved, der udtrykte lignende synspunkter som "sogneopstandene" og som fik omkring 1000 underskrifter. Sønderborger Ugeblad
5.6.1844; LASH Abt. 22, nr. 556, breve fra pastor Brag til hertug Christian August maj-juli 1844.

9. Lyna 10.1.1844.

10. Lyna 17.4.1844.

11. Lyna 20.3, 27.4.1844; Dannevirke 23.3.1844.

12. Den senere udtrådte $C$. Iversen, Fredsted, fraregnet. Lister over optagne medlemmer med biografiske oplysninger hos H. R. Hiort-Lorenzen: Den slesvigske Forening, passim.

13. Lyna 8.6.1844.

14. Sønderjyllands Historie IV, s. 300-305.

15. Lyna 12.6.1844.

16. LASH Abt. 63 nr. 906.

17. H. V. Gregersen (udg.): Laurids Skaus brevveksling med politiske venner $\mathrm{i}$ Sønderjylland, Aabenraa 1970, s. 120ff, 124. Kong Christian VIII.s dagbøger og optegnelser, IV.2, Kbh. 1995, s.501. Amtsforvalter G. F. von Kroghs beretning 7.8.1844 til hertugen af Augustenborg i LASH Abt. 22 nr. 567.

18. Lyna 18.12.1844.

19. Slesvig-holstenismens historie i Haderslev er udførligt beskrevet af Henrik Fangel i Haderslev bys historie 1800-1945, bd. 1, Haderslev 1975 , s. $315-366$.

20. Lyna 30.10 . og 2.11.1844.

21. Lyna 19. og 26.3., 2. og 9.4.1843. Jfr. Proben schleswig-holsteinischer Pressfreiheit. Zweiter Theil. Die deutsche Bewegung in Schleswig-Holstein. Leipzig 1844, s. 181-234.

22. Lyna 16.7.1843.

23. Lyna 28.2, 1., 4. og 11.5.1844.

24. Lyna 2.7.1845.

25. Den efterfølgende redegørelse for foreningens historie hviler, hvor ikke andet oplyses, på foreningens protokol, som opbevares sammen med dens øvrige arkiv på Haderslev Byhistoriske Arkiv. En kopi heraf findes på 
LAÅ. Referater af foreningens møder er indført i kronologisk rækkefølge i protokollen.

26. Om dr. Marcus se Henrik Fangel: Dr. J. A. Marcus. Læge i Haderslev 183251. Et bidrag til slesvig-holstenismens historie i Haderslev. Haderslev-Samfundets Årsskrift 1969-72, s. 5-45, især s. 20-28.

27. Fangel: Dr. J. A. Marcus, s. 21.

28. Medlemsliste for Bürgerverein 1845 (i privateje hos Bürgerverein).

29. Statutterne er trykt i Lyna 12. og 16.7.1845.

30. H. V. Gregersen (udg.): Laurids Skaus brevveksling med politiske venner $\mathrm{i}$ Kobenhavn, Aabenraa 1966, s. 148, 290 (brev til Orla Lehmann 11.7.1845).

31. Lister over optagne medlemmer med steds- og erhvervsangivelse findes $i$ foreningens protokol under de nævnte modedatoer.

32. Kort over Den slesvigske Forenings medlemmer hos Schultz Hansen: Den danske bevægelse, s. 362 .

33. Den slesvigske Forening: Schultz Hansen: Den danske bevægelse, $s$. 374.

34. Fødestedsoplysninger i folketællingen fra 1845 på LAA. Jfr. Georg Hanssen: Statistische Forschungen über das Herzogthum Schleswig. II: Das Amt Hadersleben, Altona 1833, s. 10f.

35. Lister over stæendermedlemmer efter valget 1841 hos Hans Jensen: De danske stænderforsamlingers historie, II, Kbh. 1934, s. 80f, 83.

36. Blandt bilagene til protokollen findes seperate medlemslister for Aabenraa og omegn og Rendsborg.

37. Stillingsbetegnelser på grundlag af folketællingen 1845 i LAA.

38. Statutter i Den slesvig-holstenske patriotiske Forenings arkiv.

39. Nordslesvigsk Tidende 24.11.1849.

40. Den slesvig-holstenske patriotiske Forenings arkiv, brev fra A. von Krogh til Haderslevforeningen, udat.

41. Om industriudstillingen: Lyna 15.10.45, 14.1., 17.6., 4.7. og 23.9.46.

42. Om dyrskuet: Lyna 10.1., 8.4., 17. og 27.6.1846.
43. Ifølge Dannevirke 17.6 .1846 var tilskuertallet 5-6000.

44. Lyna 10.4., 2. og 23.6. samt 7.7.1847.

45. Lynas referat er dog betydelig mere afdæmpet som følge af regeringens skærpede kurs efter det måbne brev«. Dannevirke bestred Lynas angivelse af deltagerantallet 7. og 10.7.1847.

46. Bilag nr. 2 til protokollen: Statutter for den tilsigtede oprettelse af spare- og låne-kasser $\mathrm{i}$ hertugdømmernes landdistrikter, Haderslev 1847. Lyna 11.7., 7. og 10.10.1846, 13.1.1847.

47. G. Japsen: De nordslesvigske sparekassers historie, Aabenraa 1970, s. 333.

48. Japsen anf. værk. s. 54-61.

49. Lyna 8., 18 . og 22.10., 13. og 24.12.1845 samt 24.1.1846.

5. Kong Christian VIII.s dagboger og optegnelser, IV.2, Kbh. 1995, s. 612.

51. Bilag 1 til protokollen. Lyna 8.10. og 5.11.1845.

52. Lyna 17. og 24.6., 11.7.1846.

53. Det »åbne brev« er aftrykt $i$ Sonderjyllands Historie IV, s. 326.

54. Lyna 26.8. og 2.9.1846.

55. Lyna 2.9.1846.

56. Kong Christian VIII.s dagbager og optegnelser, IV.2, Kbh. 1995, s. 736.

57. Lyna 19., 22. og 26.5.1847.

58 . Om denne og den politiske udvikling 1848-50, se Holger Hjelholt: Sonderjylland under Treårskrigen, I-II, Kbh. 1959-61.

59. Nordslesvigsk Tidende 28.10.1848.

60. Bundesarchiv Aussenstelle Frankfurt, Abt. 51, Deutsche Nationalversammlung, nr. 423 (løbenr. 133).

61. Nordslesvigsk Tidende og Itzehoer Wochenblatt 18.11.1848.

62. LASH Abt. 63, nr. $1384 \mathrm{I}$, petition nr. 58.

63. Nordslesvigsk Tidende 19.12.1849.

64. LASH Abt. 63, nr. 1384 I, petition nr. 62.

65. LASH Abt. 22 III EE, nr. 48a, hektograferet oversigt over adresser til statholderskabet, februar 1850 .

66. Se herom G. Japsen: Den fejlslagne germanisering. Aabenraa 1983. 